\title{
A Case Report on Mandibular Second Molar Regarding Single C-Shaped Canal
}

\section{ANIL K TOMER', NITISH MITTAL*2, AKANKSHITA BEHERA³, NEHA MITTAL4}

C-shaped canal variation is commonly seen in mandibular second molars. Extra canals is not always a variation in root canals. Radiograph is a must for the identification of single canal. Thorough idea of the proper anatomy of root canals is utmost important to diagnose the variations.

KEYWORDS: C- Shaped canal, Cleaning and Shaping, Variations, Configurations

\section{INTRODUCTION}

To ensure proper treatment a clinician should obtain certain protocols of cleaning and shaping along with a thorough idea of the root canal anatomy. ${ }^{1}$ The mandibular second molar have two roots: A mesial root and a distal root. Variations in canal anatomy is important to diagnose. $^{2}$

A clinician should always keep in mind about the configurations of the root canal systems because it is not necessary that variation should be in form of extra canals, there can be lesser number of canals present. ${ }^{3}$

\section{CASE REPORT}

A 30-year-old female patient complained of pain of her lower back tooth. Intra oral examination revealed carious tooth 37 with pulp involvement (Figure 1).

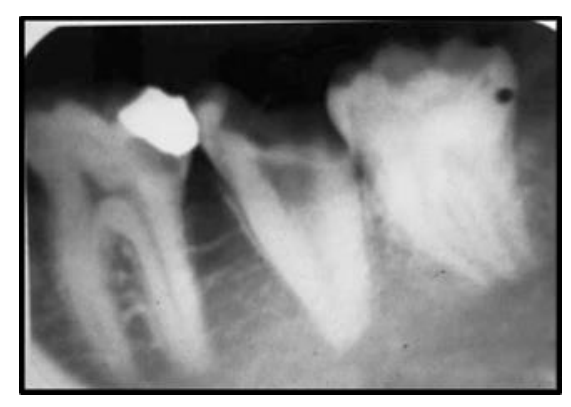

Figure 1. Carious Tooth 37 with Pulp Involvement

Access cavity was opened after Local Anaesthesia. Working length was taken with apex locator (Figure 2).

Cleaning and shaping was done using hand $\mathrm{K}$ file and rotary files along with copious irrigation. The obturation was done using warm vertical condensation method (Figure 3)

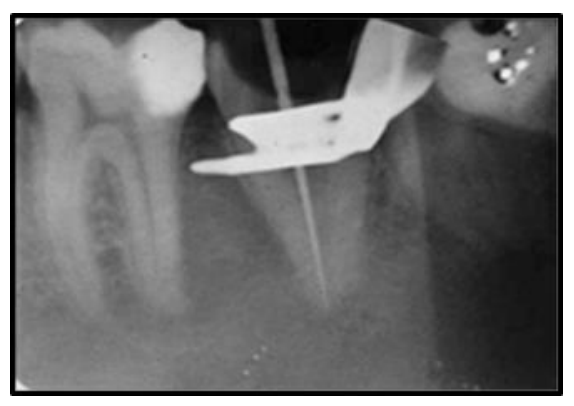

Figure 2. Working length determination

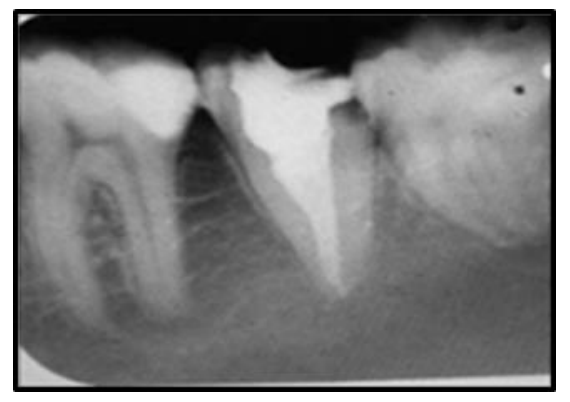

Figure 3. Obturation

\section{DISCUSSION}

Usually mandibular second molars have two roots. But there are a wide range of variations in root canal configuration. ${ }^{4}$ There is possibility of tooth having single root canal. ${ }^{5}$

The C-shaped root may also be formed by coalescence because of deposition of the cementum with time. ${ }^{6}$ Melton et al., in 1991 classified C-shaped canals on basis of cross-section. ${ }^{7}$ Fan et al., in 2004 modified 
Melton's classification into the following categories ${ }^{8}$ :

- Category I ( $\left.\mathrm{C}_{1}\right)$ : The shape was an interrupted " $\mathrm{C}$ " with no separation or division.

- Category II ( $\left.\mathrm{C}_{2}\right)$ : The canal shape resembled a semicolon resulting from a discontinuation of the " $\mathrm{C}$ " outline.

- Category III ( $\left.C_{3}\right)$ : Two or three separate canals (highest incidence).

- Category IV $\left(\mathrm{C}_{4}\right)$ : Only one round or oval canal in that cross-section.

- Category V $\left(\mathrm{C}_{5}\right)$ : No canal lumen could be observed (which is usually seen near the apex only).

The classic feature of c-shaped canal is the presence of web which interconnects the canals. But there is more chances of failure of endodontic treatment due to large amount of debris which seems difficulty in removal, so proper irrigation is of utmost importance. Following proper biomechanical preparation obturation is done with thermoplasticized obturation technique with warm vertical compaction. ${ }^{5}$

\section{CONCLUSION}

This case report presents single C-shaped canal. Thorough knowledge and proper diagnosis should be done to diagnose a C- shaped canal. Proper cleaning and shaping is of utmost important along with copious irrigation.

\section{REFERENCES}

1. Cleghorn BM, Goodacre CJ, Christie WH. Morphology of teeth and their root canal systems. In: Ingle JI, Bakland LK, Baumgartner JC. Ingle's Endodontics, 6 th ed., B C Decker Inc., Hamilton, 2008:151-220.

2. Rahimi S, Shahi S, Lotfi M, Zand V, Abdolrahimi $\mathrm{M}$, Es'haghi R. Root canal configuration and the prevalence of C-shaped canals in mandibular second molars in an Iranian population. J Oral Sci 2008; 50:913.

3. Gopikrishna V, Bhargavi N, Kandaswamy D. Endodontic management of a maxillary first molar with a single root and a single canal diagnosed with the aid of spiral CT: Aa case report. J Endod 2006; 32:687-91.

4. Raghavendra SS, Napte BD, Desai NN, Hindlekar AN . Single $C$-shaped canal in mandibular first molar: A case report. J of Cons Dent 2005; 18 (2): 168-171

5. Elumalai D, Kumar A, Tewari RK, SK, Andrabi SMU , Iftekha HR, Alam S. Management of C-shaped root canal configuration with three different obturation systems. J of Cons Dent 2015; 4 (1): 25-28.

6. Manning SA. Root canal anatomy of mandibular second molars. Part II. C-shaped canals. Int Endod J 1990;23:40 -5

7. Melton DC, Krell KV, Fuller MW. Anatomical and histological features of C-shaped canals in mandibular second molars. J Endod. 1991 Aug;17(8):384-8.

8. Fan B, Cheung GS, Fan M, Gutmann JL, Bian Z. Cshaped canal system in mandibular second molars: Part I-Anatomical features. J Endod 2004;30:899-903.

\section{AUTHOR AFFILIATIONS:}

Professor and Head

PG Student

PG Student

Department of Conservative Dentistry and Endodontics, Divya Jyoti College of Dental Sciences and Research, Modinagar

4. BDS, Divya Jyoti College of Dental Sciences and Research, Modinagar

*Corresponding Author:

Dr. Nitish Mittal

PG Student

Department of Conservative Dentistry and Endodontics

Divya Jyoti College of Dental Sciences and Research,

Modinagar, Ghaziabad, Uttar Pradesh 201204, India
For article enquiry/author contact details, e-mail at: manuscriptenquiry.ihrj@gmail.com 